some obstrvation of methods of treatment adopted by others and by myself in dealing with the peculiar classes of ailments assembled under the generic name of ucerine intlammation and ulceration.

First, as regards the uses of injections. These may be learned by their failures. They are insufficient for the cure of ulceration, if it has existed for some time, and I have no satisfactory evidence that they cin cure this condition effectually under any circumstances. They are not able to cure lencorrhcea in the great majority of cases. I have seen it return again and again after the injections have been discontinued. They are useless for the cure of inflammatory induration and hypertrophy of the cervix, and they are equally ineffectual in the sole treatment of the spongy, indolent, patulous, and ulceratel cervix occasionally met with in obstetric practice. I can furnish abundant proof of the correctness of these statements, and it is much to be desired that they were able to win the assent of all who are engaged in this department of our art-for our own credit and for the welfare of the sufferers.

They are of yreat use notwithstanding; but it is only in their secondary position as adjuvants to a higher class of remedies. For the relief of pain, for the removal of acrid discharges, for the deodorization of offensive, and for the suppression of ex. hausting fluxes, injections are of value. They are of nse for giving tone to a relaxed and weakened organ, and as as for the support of the womb having a tendency to prolapse. Conjoined with judicious and appropriate cauterization, they are of the greatest use in hastening the cure of the inflamed and nlcerated womb; and it is of common observation, that patients who are careful in the use of injections, (as in private practice,) get well very much quicker, and with less pain, than those who (as at public institutions) neglect this means. When the cure is complete, injections are still of much $n=e$, but it is most diffi. cult to convince the patient on this point. In married life it ought to be easy to induce the patient to persist in this most healthful duty; yet the reverse is the fact.

The substances adapted for injections in commonest use are of the stimulant and astringent kind. Of these, notwilhstanding the opinions and practice of others, I consider the sulphate of zinc the most unjustifiable. I think I have seen it the cause of much irritation and mischief, and it is difficult to believe that the constant use of so poisonous a substance over so large a surface of mucous membrane can be other than injurious. The nitrate of silver is another substance most unsuited for injec. tion, yet very frequently ordered for use. The mucus of the vaginal canal instantly decomposes it if used in a weak injec. tion, and if in a stronger form, the excoriation of the external parts, together with the mischief inflicted on the linen, hands, and utensils of the patient, preclude its repeated employment. I have made use of a variety of substances for this purpose, but as simplicity and economy are chiefly of consequence in a daily matter of this sort, the result arrived at is, that a solution of alum, either alone or in decoction of oak-bark, is, after all, the best and most effective injection we can prescribe. A mixture of equal parts of tannin and alum forms a more elegant, but also more costly substance as an astringent. For the anodyne injections, solutions of belladonna and of ovinm are the only serviceable remedies, and to these may be added the liquor plumbi and hylrocranic acid with occasional good effect. For emollients, milk and-water, linseed-tea, barley water, and thin starch or gruel, are very valuable. The injection of gases and vapours is a very uncomfortable proceeding, and is not always free from a certain amount of risk, but considerable relief may sometimes be thus obtained when other means are useless.

those most valuable are the carbonic acid gas and the vapour of chloroform.

Lastly, of the instruments for injection. Gooch's bent-pipe instrument is a cumbrous and dangerous apparatus, very apt to get filthy, and to inflict injury on the cervix. The glass "female syringe" is a most absurd con rivance for cleansing a canal so capacious as that for which it is intended. It is also often broken, and sometimes within the canal itself. The ordinary pump, with elastic tube, has the disadvantage of requiring the assistance of a second person for its use. For the use of the poorer classes a simple and excellent instrument was con. trived by me some years ago; it consists of a piece of gutta percha tube, five feet long, fitted at its upper end with an inch or two of elastic tubing: this could be slipyed over the mouth of a common kettle, and the other end being placed in its proper position, the inversion of the kettle produced a constant stream of water of sufficient force to well wash out the canal. The same object may be also accomplished (and this method is largely used in France) by the use of a long syplion, the upper end bein; imnersed in a reservoir of water, and the lower re. tained in the canal by the patient. The French have an extra. ordinary variety of instruments for this purpose, amongst the most useful of which is one on the principle of the moderator lamp. Without exception, however, the most commodious and useful of all instruments for uterine injections is the elegant arrangement known as Dr. Kennedy's, and now becoming much used in this country. It may be employed either for gases or for fluids; as a douche or as an enema. An ingenious contrivance, known as the barrel syringe, marle of caontchouc, is also usefal for this purpose; but the action of its valves is less to be relied upon than in the former instrument. For general use the douche just named is the best of all the varied forms of instrument for raginal injections, and it will probably ultimately replace every other kind. Its valves require occasionaly a little looking after and cleansing, but this is simple enough, as they merely consist of two metallic peas.

This article may be truly said to be drawn in "first lines," but experience has long satisfied me of the great importance of these homely remarks. If it be admitted that injections have a remedial value, it is certainly the duty of the medical man to take care-lst, that they be employed for such uses as they will most surely subserve; 2 nd, that only those substances be used which are adapted for those ends; and lastly, that the instrument for their employment is a simple and efficient arrangement. Instances of failure on all these points are so common as to justify this note on a very commonplace subject.

Sloane-street, May, 1862 .

\section{CASES IN SURGICAL PRACTICE.}

By JOHN IVIBLIN, L.R.C.P. EDIN.,

PAESTDENT OE THE SOUTM HAYTS MEDICLL AND SURGICAL SOCIETY.

THE following cases have lately occurred in my practice :STONE IN THE BLADDER; IITHOTOHY.

George C_- aged fifty-seven, a native of Lyndhurst, had suffered for some years past from all the most prominent and painful symptoms of stone in the bladder. In the course of the last year he had been sulject to every variety of treatment for the cure, as was supposed, of disease of the kidney, enlargement of the prostate gland, and stricture of the urethramaladies which existed in the imagination only of the gentle. man whom he consulted. The early history of the patient's condition of health afforded abundant evidence of bis having been the subject of scrofulous inflammation of the joints, and necrosis of the femur and humerus. Towards the litter end of $1861 \mathrm{my}$ opinion was requested on the case. The blailder was examinel, and found to contain a stone of moderate dimensions. On the 7 th of January of the present year he was admitted into the wards of my private establishment, and after he had undergone some preliminary treatment, a day was named for the performance of the operation.

On the listh of Jannary the patient was fully submitted to the influence of chloroform by Dr. Henry Palls, a gentleman thoroughly conversant with all requirements calculated to en. sure its successful administration, and to whom I am under many obligations for similar assistance on various occasions. When the patient was placed on the operating table, a fullsized grooved staff, No. 14, formerly belonging to my preceptor, $\mathrm{Mr}$. Liston, but now in the possession of Mr. T. Carr Jackson, was with the greatest facility introduced into the bladder. After the ordinary external incision was made, it was found impossible to abduct the thirh from the pelvis, in consequence of a pretty firm, although false, anchylosis of the hip.joint, the result of old-standing disease. There existed also partial anchylosis of the knee-joint, so that the left leg was of necessity held firmly bent in a position almost perpendicular to the body. The result was that the perineum, naturally narrow, was rendered much more contracted, and the space in which the necessary manipulations had to be executed was limited in the extreme. The inconvenience caused thereby was apparent to everyone as soon as the first incisions were made; for there was but little room for the operator's fingers, and his lateralizing movements were cramped and considerably impeded. After some little delay, however, the bladder was reached, the incision of the prostate gland being only sufficient to admit the point of the forefinger. On the introluction of the forceps, the stone was at once felt at the left side of the apex of the bladder, and was readily grasped; but on making the attempt to withdraw it from the bladder, it unfortunately slipped from the jaws of 
the instrument, and on the next effort being made it could not be felt or detected in its altered position. The bladter was now searched most carefully by means of every kind of forceps, and as it was thought that the prostate was enlarged, it was supposed that the stone lay imberded behind this gland. The curved forceps was intronced again and again, but without avail. At this juucture, a sound with a shert abrupt bet $k$ was introduced into the blalder, with the concavity of the curve uppermost, aud as it was passel in this manner under the pubes, the stone was ascertaiued to be lying in the bladder inmediately behind and above this part. The position of the stone being now male known, Mr. H. Smith, of King's College Hospital, who had done me the favour to take chirge of the staff, male pressure on the lower part of the abdomen, when the stone was dislodged from its position, and fell as it were into the jaws of the forves. Here, again, another acoident occurred by the breaking of the stone inte two preces, necessitating a second intruation of the forceps before the whole could be removed. The proceedings of the operaicon were ne cessarily prolonged in consequevee of the existing complications; but most fortunately the patient did not surtain the loss of mora than one tablespoonful of blood, and as it was ascertained that the stone was not larer than a chesnut, the incision of the prostate was very liusted, si) that the rangers, which might have been of the most formitable character in such an operation, were reduced to the least derree consonant with the execution of such a complicated and difficult proce. dure.

The operation concluded, the man was removed to bed; an anodyne lranght was administered, and, by the further means of a suppository of one grain and a half of opium, iutrodnced into the rectum. he passed a tolerably cood nught.

Jan. 19t!. - Free from pain of every description. Complains of great thirst. Oruered to drink coviously of barley-water and beef-tea every two or three hours; to repeat the anodyne draught and suppository.

20 th. - Pussed a good night; pulse 75 . Urine voided by the urethra in small quantities geveral times during the dis. Or. dered a mutton chou for dinner; to repeat the night draught withont the suppository.

2lst and 22ud.-Passed excellent nights. Takes plentifully of everything that is given to him, and states that he is more comfortable than he has been for five years.

24th. - Urine snells very ammoniaval; contains phosphates in abundance, with vesical epithelial scales, and mucus-corpuscles. To take tifteen minims of the perchloride of iron every three hours.

$29 \mathrm{rh}$.- Tho general health and strength greatly improved.

Fcb. 10th.-Passed a tolerably large quantity of urine per nrethram. 'The wound in the perineum, to all appearance, is prozressing favourably.

10th to 29 th. - It became evident that the wound in the perineum had lost its healthy and granulating appearance, and that nearly the whole of the nine vassed through this channel. All possible means were adopted to invigorate the man's gene. ral condition of health : he was fed upon every variety of flesh and heat formius material; he was ordered full doses of ferru givous prepar ations, which were strongly indicated by his pallid and anxmic contenance; his bladder was at times injected with a sulution of dilute nitric acid; he was keyt in bed for a week at a tine, with a catheter retained in the blarler: but neither time nor treatment had accomplished much towards restoring the natural condition of parts up to a perod of ten weeks from the date of the operation.

Under such crumstances it was deemed advicable to give the man the benefit of a change of air; he was accordingly sent to his own home in the New Forest, where his health and strenth are rapilly improving; and after one month's resiclence in the country, he himself reports thas "the uriue is beginning to go right," or through the natural passage.

AMPUTATION AT THE SHOULDER-JOTYT.

In this case the patient was a man on whom I operated twenty years since, The man attended a late meeting of our Society. 'The members were much struck with the dexterity the man evinced in dressing and undressing, and in tying his neckerchief in a double bow. He said he found very little inconvenience from the absence of an arm, llustrating the adage that " use is second nature."

CASE OF REMOVAL OF A SURCUTANEOUS BURSA MIUCOSA OF THE KNEE-JOINT.

The patient was a sailor, who, in the exercise of his calling, had been for five years past mnch inconvenienced by repeated at:acks of inflummation of the bursal appendage in question. With the view of effecting a radical cure of the rlisease, I advised its removal. On cutting into the cyst or bursa after the operation, its walls were found to be thickened to an extent but seliom ofsrrved; the contents of the swelling consisted of lark grumons lluid and cheeso-like ruatter, and fibrous bands of the diameter of a crowquill extencled from ne side of its cavity to the other. I consilered that the ordinary mode of treatment in such cises, by connter-irritation, seton. \&c., would sot have been moluctive of the slightest benetit to this patient. Sou hampton, Miny, 1862

\section{筑irirn}

OF THE PRACTICE OF

\section{MRUICINE AND SURGERY IN THE}

\section{HOSPITALS OF LONDON.}

Sulla est alia pro certo noscendi via, nisi quam plurimas et morborum et jissertionum hiftoras, tam aliorum proprias, eollectas habere et inter se comparare.-Monoasi. De Sed. et Caus. ITorb., lib. 14. Frocenium.

\section{WESTMINSTER HOSPITAL.}

EMPYEMA AND PXEUMOTIORAX AFTER ACUTE PLECRISY; PARACENTESIS TWICE; CONPLETE RECOVERY UNDER TEE USE OE DRATNAGE-TUBES.

\section{(Under the care of Dr. IIxcham.)}

THE remarkably good effects of the use of a drainage-tube, passing into the chest by one opening, and out by another, in a depending position, are well exemplihed in the following case. The value of this mode of treating empyema canuot, indeed, be over-estimated, and, providing that other cirenmstances are favourable, it holds out a more positive hope of cure than any other plan that is recommended. Dr. (toodfellow had two examples under his care at the Middlesex Hospital, male patients, aged seventeen and twenty-fonr, in whom this plan was entirely successful. They formed the subject of a paper read before the Medical and Chirurgical Society, which was published in the 42 nd volume of their "Transactions;" (see, also, Tre Lince't, vol. ii. 1859, p. 11.) We make the following apposite quotation from it: -

"In cases of empyema, from whatever cause induced, where there is rood ground for concluding that the lung is inexpansible, I think few will be prepared to deny the advaritage of making two openings in the operation of paracentesis thoracis, and applyin the plan of 'drainage.' The only probable exception to this is, where empyema occurs in a youns child in whom the restorative powers are strong, and the chest-wall is so elastic that it readily falls in and adapts itself to the diminished quantity of fuid witbin the chest."

In our present series of cases will be found illustrations of several of the varieties of empyema, possessing more or less interest.

F. $\mathrm{O}-$ - , arged seventeen, seaman, was attacked with acute plenrisy in August, 1860, at Cork, where he was bled, blistered, and otherwise treated for some weeks, when he came to London and was admitted into the Westminster Fospital under Dr. Fincham. At this time he was somewhat emaciated; face flushed; skin warm and perspiring; appetite fair ; urine highcoloured, but normal; pulse 140 ; respiratious 40 . He compliined of shortness of breath, cough, and some palpitation of the heart. He expectorated a listle colourless mucus. He lay habitually on the right side, with his shoulders slightly raised, which caused much soreness of the right hip, greatly interfering with his rest and sleep. The physical signs were as follows:Marked resonance of the right side anteriorly as low as the seventh rib; the same resonance extended backwards to a line corresponding with the anterior edge of the axillary region. A 